\title{
The Contribution of Catholic Friers to the Musical Education in Skodra
}

\section{Eliona Lici}

\author{
Phd. Candidate, University of Tirana, Faculty of History and Filology, Departament of Cultural Heritage
}

Email: elionalici@live.com

Doi:10.5901/ajis.2015.v4n2s2p39

\begin{abstract}
The object of this study is to analyze the valuable contribution of Franciscans and Jesuits to the development of the musical education, considering it as an inseperable part of the general education. At first the study will analyze the historical circumstances that stimulated the development of the musical education in the catholic instituticions like: Saverian College, Papnuer Seminar, Illyricum High School, Serafic College. It will also delineate the main personalities that considered the musical education as an important value in the social, moral and educational direction of the society of that time offering modestly an increase in the standart of living. So, the main pivot of this study is referring to the analyses of the subject programme of the musical education as a reflection of healthy didactic bases. The overview will be focused on the musical education programme which are reflected in different musical school publications and which are evaluated in the pedagogical musical aspect for the methodological structure used. The importance of this study stands in the unquestionable value that carry the programmes of musical education to the history of musical pedagogy in Albania. The research method will be based on the exploitation of different funds of the Central National Archive to find early evidences about musical education.
\end{abstract}

Keyword: Music education, Franciscans College , Jesuits

\section{Introduction}

The paper is focused on analyzing the valuable contribution of Franciscans and Jesuits which remains a very significant historical phenomenon that should be evaluated because thanks to this orders northern Albania and especially Scutari represented the most important spiritual center of literary and artistic culture of the country. The selection of this theme comes as the product of the research for doctoral thesis "Musical education in the first half of the twentieth century". The theme is one of the basic pillars of musical art in Albania and it aims to provide a modest contribution in presenting music programs in clerical institutions during 1900-1944.

\section{The object of the study}

In accordance with the objectives of the paper the issues are based on two major axes: in cultural - historical and pedagogical axis of music education. The second issue is multifaceted as it analyzes the place that music education programs held in clerical schools, as well as the encouragement that offered music education to the increase of musical activities throughout the country, becoming so the starting point for the professional music.

\section{Research methodology}

The process is based on tracing the document in CSA, in the study literature and press of the time in the National Library as well. In the Central State Archive is particularly researched the Franciscan Fund, order nr.133, Jesus fund nr.132, Archbishopric Scutari, Ministry of Education F.195. The research it is not completed here, as it will be enriched later with facts from Franciscan Library and Historical Museum of Scutari, from which information is selected to construct this important part in the history of musical pedagogy in Albania.

In the early nineteenth century the Catholic clergy opened many schools that were at service of the educational development of the Albanian citizens. Only in Scutari between 1800 and 1861 were opened about twelve schools, eight for boys and four for girls, (The star of light, 1933:242 ) with a primary school structure and religious content. In 1859, 
Jesuit order opened Pontifical Albanian College and in 1860 ( Skëndi :2000) .

In 1877, dates the opening of Saveriane College (Collegium Pontificum Albanie) which started its activity in a challenging political and social situation, facing difficulties..... Ottoman invaders, obstacles of bigotry and local anticlericalism (Drini :2011)attacks. A special importance in this college received Albanian lessons given by personalities like Father Justin Rrota and Ndre Mjeda, a linguist and author of texts and poets who cultivated and encouraged love for the native language.

\section{Documents about music education in clerical institutions}

From the documents found in CSA, fund of the Franciscan Order 133, D.1359, in a study of Albanian music, although undated, we are introduced to several scores which inform us that in addition to general education, in the Pontifical seminar "Xhakoi" was done musical education too. This is not presented in the document, but the fact that the scores are in this folder and the two of them bear the stamp of the clergy, proves that these works have been put in function of the artistic education of the students. One of these scores, which hold the seal of Pontifical Seminary, is a famous choral of the world repertoire, authored by G. Rossini-n. Choral is transcribed for contralto voice and in the manuscript is presented the melody line belonging to the vocals. Besides the text in Italian, written in purple color, the score contains the text translated into Albanian, in black color. The score, in the existing state in the fund of CSA, appears damaged as a result of the long time and inappropriate preservation conditions: the writing in Albanian can be barely decoded; from the moisture the purple color has left spots on the score. In general the score appears pale, creased, jaundiced, too dry as a result of the moisture, and touching it, it could be felt its dilution. Writing in two colors, purple and black is perfectly clear. Title calligraphy is not the same with the fonts of the text in the score.

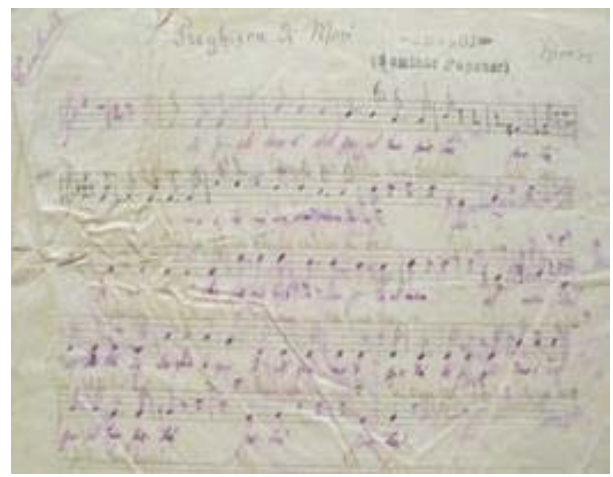

Facsimile of the score "Preghiera di Mose"

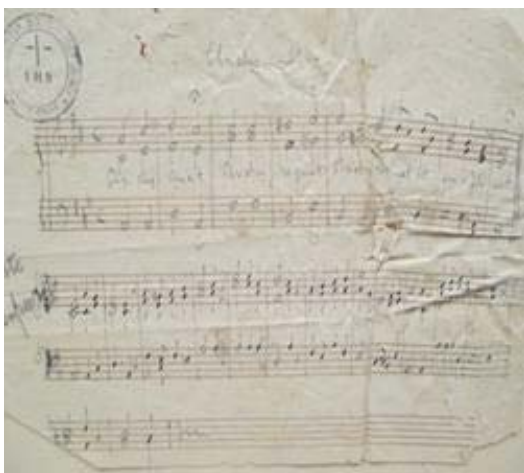

Facsimile of the score "Christus Vinit

"Vinit Christus", a manuscript equipped with the seal of the clergy, copied by hand, as it can be seen is for four voices, unaccompanied by the piano, a cappela, with a simple rhythm, without date and year. The striking fact of the score is the composition in four voices, which implies a growing professional claim in terms of musical education. The score is found in the Folder 1359 in the same place with the preceding manuscript. What catches the eye immediately it is the fact that it is sung in four voices, something that enhances the professional claim about a qualitative step towards music education requests. The same it can be said about music notebooks named Rosina (which according to the tasks belong to the year 1946). We think that there is a mix of materials in a folder that belong to different chronologies. Below we will present an edition of Saveriane College of 1933 for elementary classes, Music Notices - a summary of songs for primary classes " This edition, is by far almost unknown about its musical elements, from the keeping of the correct time (meter ), to the grafting signs, singing intervals, singing in two voices, singing solo, chorus etc. From the data of the documents in the Central State Archives we do not get introduced with additional materials which present evidences of the literature used, so this edition remains a valuable documentary source for the heritage of school musical publications. 


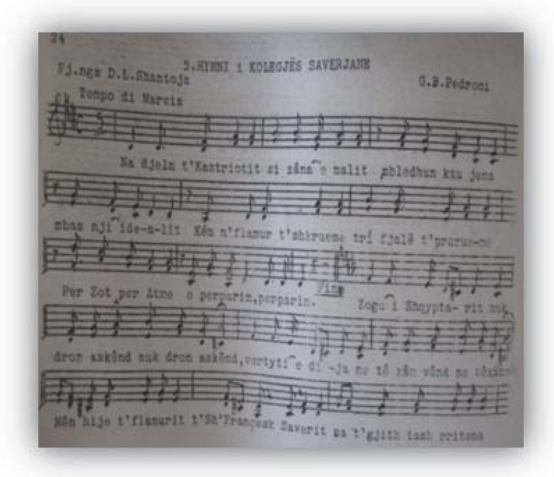

Facsimile of the book cover of Saveriane College, 1933

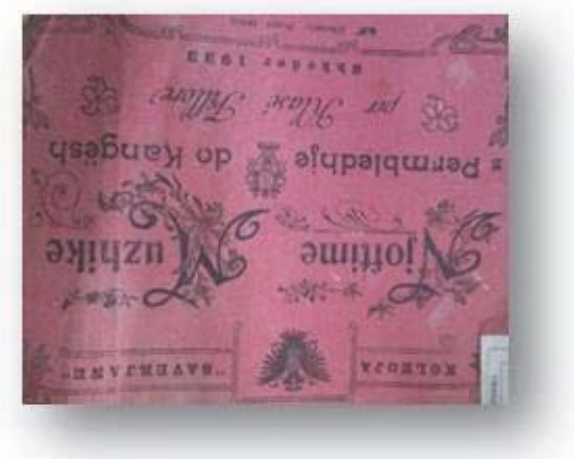

Facsimile of Saveriane "College Anthem" composed by GP Pedroni
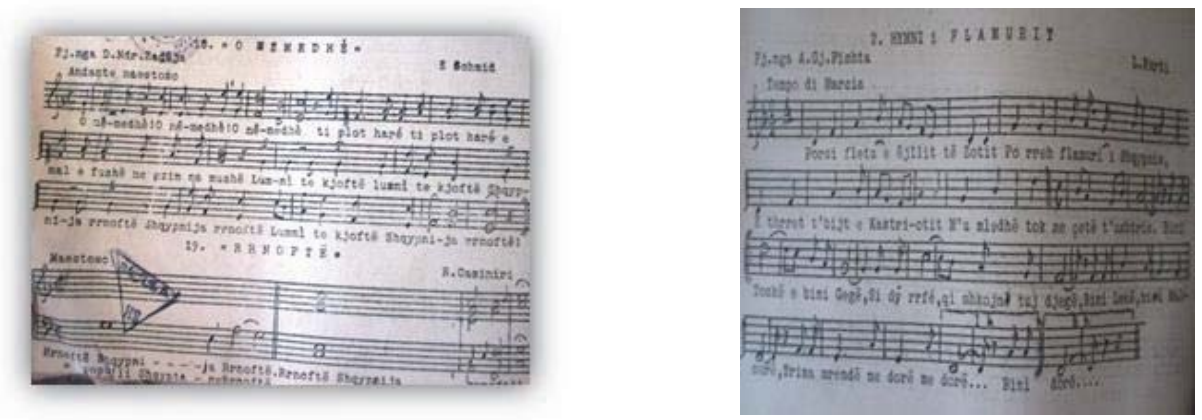

For the motherland"with music by Schmid and text by Dom Ndre Zadeja "Flag Anthem" with music by L.Kurti text Father.Gjregj Fishta

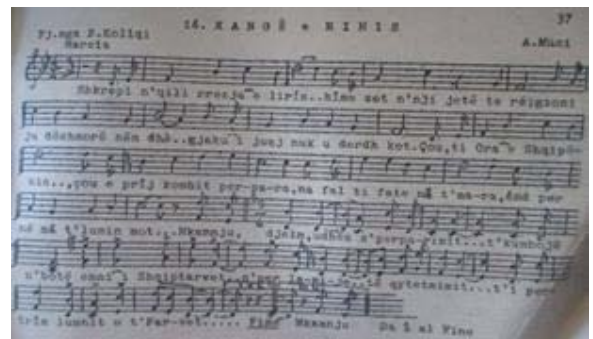

"Youth Song" composed by A.Muçi and text by E.Koliqi

Initially, this structure makes the student more skillful regarding language and musical communication competencies in order to achieve learning outcomes in terms of musical theory. Theoretical content of the book is an effective methodology for teaching the essential musical elements. Fluted education as the basic methodological element of the formation of the musical ear is realized with simple interval exercises and songs with one or two voices, which refer to the degree of intonative and rhythmic difficulties. The book contains more than 9 songs by Albanian and foreign composers. We can note, that the structure of the book based on imparting theoretical and practical knowledge, adheres to European didactic standards by treating fundamental aspects of music pedagogy in order to offer a better education in music.

Franciscan Primary School started its activity in 1861. In 1897, to the 5 grades is added a plotnore (sixth grade) whose curriculum included faith, reading, writing, grammar, orthography, drawing, gymnastics, song, geography, nature history, math and geometry.(MArku :2012) In the years 1897-1902 was led by foreign directors. Years twenty of the last 
century were crucial because at the head of the school was Gjergj Fishta, Albanian leader who turned the school into a significant hearth of the spread of inspiration and national feelings. What we notice about music education is the increase of the quantity of classes to three classes a week creating the right conditions for the growth of musical activity. (Marku, 2012,pp.133) The performance of melodrama "Shqiptari i Gjytetnuem" by Gjergj Fishta in December 19, 1911 on the occasion of 50th anniversary of the Franciscan school represents a high level of musical education. Besides this in 1917 was performed the drama "Juda Makabe" composed by Father Martin Gjoka. At the request of the professors Ambroz Markalaj, Father Justin Rrota, Father Anton Harapi , Father Vincens Prenushi initiated the opening of public Gymnasium "Illyricum" which was approved by Father Pal Dodaj and was opened in 1921. It is distinguished the prominent contribution of the composer and director of a wide range of musical activities in Scutari, Father Martin Gjoka (18901940). Besides teaching geography and history, he worked hard for the reorganization of the choir and orchestra at the Franciscan church.

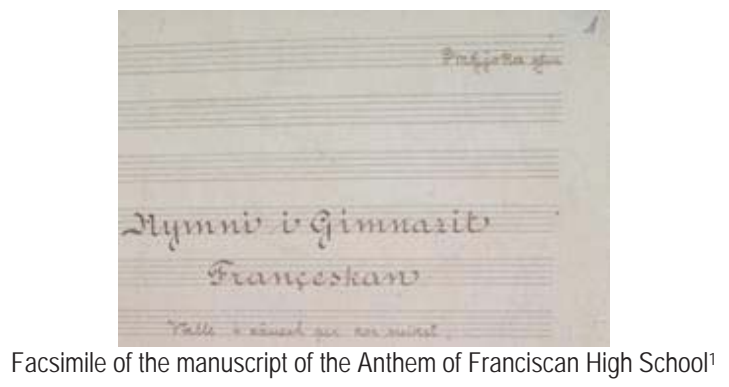

Stigmatine Sisters Normal School, Franciscan female school, a crucial institution for the preparation and education of women in Albania began its life in 1876. It was originally opened as a primary school and later urban primary school Kazazi(1994) as well. The school was private (Central State Archives:1931) and with a social science orientation. Besides education it is noted that in this school was also paid a great importance to the theatrical performances for their contribution to overall primary education. Referring to doctoral thesis on Literary Franciscan School pg.132 authored by Kastriot Mark we become acquainted with the fact that Martin Gjoka has formed the school choir and the organization of Franciscan school choir would continue the effort initiated by Father Thomë Marcozzi since1878. Father Martin Gjoka succeeded to establish a wind orchestra of 50 instrumentalists who gave concerts almost all over the country.

Serafic College of Scutari of the Franciscan missionaries, subsequent of Franciscan College of Troshani, a religious educational institution is an indicator of constant preoccupation in musical education matters. Based on the form of professional structure of the analytical program of canto speciality in this college, we can trace the coherent progressive development of musical knowledge, well planned for courses of different levels.

The elementary course

The first grade - a class of canto a week, the second grade - a class of canto a week. In the Central State Archive there is the document in which appears the specific objectives of each discipline ${ }^{2}$. Particularly we are going to present the content of the Canto subject

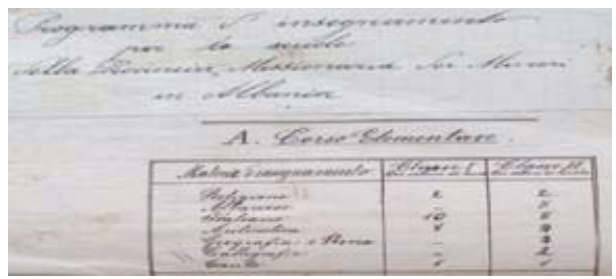

Picture 1: Facsimile of the document, the schedule of Serafik College, Scutari ${ }^{3}$

\footnotetext{
1 Central State Archives, Gjoka,M:1)

${ }^{2}$ CSA, F.133,D.1358 pg. 8

${ }^{3}$ CSA, F.133,D.1358 pg. 8
} 


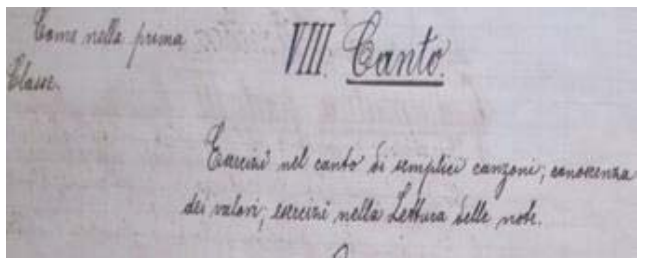

Picture 2: Facsimile of the content of the analytical program of canto in the elementary course, grade $\mathrm{I}^{4}$

The program contains (ear exercises, vocal exercises) simple singing exercises, simple listening exercises and theory elements (Quadro dei Valorie)

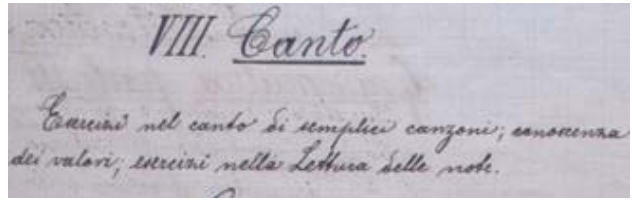

Picture 3: Facsimile of the program content of Canto, grade II ${ }^{5}$

Grade II, listening exercises and vocal exercising singing with one voice. Exercises for musical measure, keeping tempo and the recognition of notes.

Human Course B (humanity); in the table of content it is also found Canto subject, a class a week for the 3 groups.

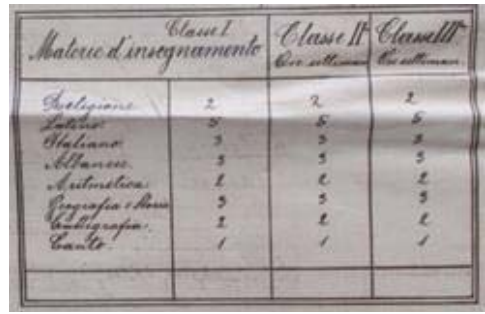

Picture 4: Facsimile of the schedule reflecting the subject of Canto ${ }^{6}, 1$ class a week.

First humane course, a program similar to the second course of elementary

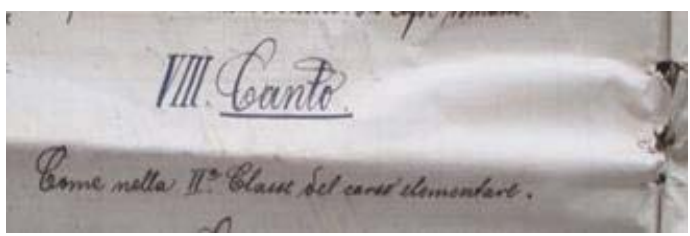

Picture 5: Facsimile of the program? 
Exercises of singing simple songs, recognition of values, reading exercises of the notes.

Exercises of singing with one voice and two voices, musical theory related to major and minor tonalities. What is especially striking is the attention dedicated to song learning; an evidence of their belief and expectations that singing offers one of the most attractive forms, simple and easily embraced by the student capacity. Artistic specific priorities included in the analytical program of the subject are used specifically to stimulate the correct singing respecting the necessary elements of music, and therefore cultivating the artistic taste, really necessary for the progress of society of the time. We consider that the program does not seem to be casual, but based on the vision of the development of the country. Below, in the program of the philosophy course, in the same college, Canto discipline is part of the three courses. Besides Latin, Italian, Albanian, German, Geography, Universal history, Physics, etc., the nature of learning of canto focuses on Gregorian Canto (monody singing in unison.) This fact is an indicator of equal value between enhanced linguistic and scientific knowledge to the education of the students.

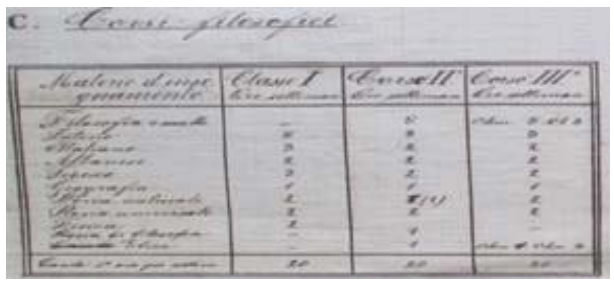

Picture 6: Facsimile of schedule project of philosophy, reflected in a class of canto a week. ${ }^{8}$

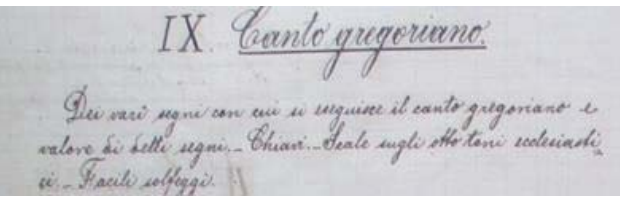

Picture 7: The program of the course of philosophy, analytical program of Gregorian Canto ${ }^{9}$

Program content, musical keys, scales with 8 ecclesiastical sounds, simple musical theory.

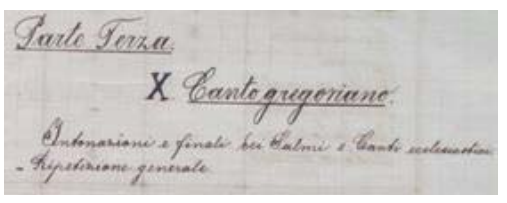

Picture 9: Facsimile of the programs, third course, final intonations of psalms and ecclesiastical songs, General Repetition ${ }^{10}$

\section{Conclusions}

When we investigated the contribution of the Franciscans and the Jesuits in Scutari we aim to:

1. To bring facts about the use of early musical education in ecclesiastical institutions

2. To reflect musical school editions and to analyze the music teaching methodology (songs and theory)

\footnotetext{
${ }^{7}$ CSA, F.133,D.1358 pg.8

8 CSA, F.133,D.1358 pg.9

${ }^{9}$ CSA, F.133,D.1358 pg.11

10 CSAF.133,D.1358,pg.13
} 
3. To examine the subject program of music, respectively of the canto subject and to analyze methodology. Analyzing this theme aims to highlight documentary evidences and to testify through them that: - the beginning of musical education in Scutari is almost the earliest in Albania.

To reflect school musical editions constructed in function of the education of students as well as the curricular programs where music education occupies an important place.

\section{References}

Central State Archives ,Found 195, file.162,pp.4

Central State Archives,Found.133, of Franciscans Order,file.1358, without year.pp.8

Central State Archives,Found.133, of Franciscans Order file.1358, without year.pp.8

Central State Archives,Found.133, of Franciscans Order,file.1358, without year.pp.9

Central State Archives,Found.133, of Franciscans Order,file.1358, without year.pp.11

Central State Archives,Found.133, of Franciscans Order,file.1358, without year.pp.13

Central State Archives,Found.personal,Gjoka.M, file.15, without year,pp.1

Drini.(2011)The establishment of Saveriane College 1877.

Kazazi,NJ.(1994)Some new data about the Histroy of education in the Scutari Territory, scientific bulletin Scutari pp.75-76

Marku,K.(2012).Doktoral thesis,Franciskan literary school of Scutari,pp.133

Rrota,J.,,Hostry of Albanian Alphabet” The Star of light”,Nr.5 Scutari,May.pp.223-250

Skëndi,S.(2000) Albanian national Awakening,Phoenix\&communication and book house,Tirana. 